\title{
Istanbul 2008
}

\author{
By Ron Holloway
}

Spring 2009 Issue of KINEMA

\section{7th ISTANBUL INTERNATIONAL FILM FESTIVAL}

Ask festival director Azize Tan why she was using every opportunity available to celebrate the current revival of Turkish cinema at the 27th Istanbul International Film Festival (5-20 April 2008), and she would tick off any number of reasons. Last year, for instance, Orhan Pamuk, the 2006 Nobel Prize Winner for Literature, served on the international jury at Cannes. Further, the Palm for Best Screenplay was awarded to Turkey-born, Germany-based Fatih Akin's Auf der anderen Seite (The Edge of Heaven), a German-Turkish co-production. Also, before this year's IIFF even began, the city was alive with the rumour that Nuri Bilge Ceylan's Uç maymun (Three Monkeys) was likely headed for the Cannes competition - as, indeed, it was. Finally, at the close of the Istanbul festival, the international jury headed by German cinematographer Michael Ballhaus awarded the Golden Tulip to Semih Kaplanolu's Yumurta (Egg), a Turkish-Greek coproduction previously screened to critical praise in the Directors Fortnight at the 2007 Cannes festival. In fact, Semih Kaplanolu, whose Egg had already won last October a bundle of national awards at the Antalya Golden Orange Festival, is currently being hailed as the third key figure in a trio of outstanding Turkish directorial talent, alongside Nuri Bilge Ceylan (Climates, 2006) and Zeki Demirkubuz (Fate, 2001).

The remarkable element about Egg is its reverse chronological position in Semih Kaplanolu's planned trilogy about a poet coming to terms with his past and present. In other words, viewed from this angle in the Yusuf Üclemesi (Yusuf Trilogy), the final chapter only hints of what the viewer might expect in the earlier portions of Yusuf's life in the forthcoming films titled Süt (Milk) and Bal (Honey). In Egg, when the poet Yusuf returns to his native village for the death of his mother, he meets in the rundown family house the young and mysterious Ayla, an unknown cousin who had been caring for his mother for the past five years. When Ayla requests Yusuf to fulfill his mother's dying wish to sacrifice a lamb at the shrine of a saint in her honour, the journey to the shrine at the edge of a crater lake in the mountains triggers painful memories of the past and feelings of guilt. The pair attend a wedding banquet before a blanket of snow cuts the pair off from the village and isolates them in the mountains.

Asked at Cannes why he was shooting the films in reverse order, Semih Kaplanolu explained that the trilogy was conceived as "a longish cinematographic flashback. I hope in this way to narrate the burden and pain of passing time and invite everyone to remember and think about his own life." Further, he underscored the poetic aspects of the trilogy as a whole. "We all have mothers, and it is highly possible that much is hidden during the time we spend with them and the time we are no longer able to be with them." And he ended on this philosophical note: "I view time as the raw material of cinema." Take Kaplanolu at his word, and the Yusuf Trilogy bears a close resemblance to Satyajit Ray's classic Apu Trilogy, the Indian masterpiece that embraces a struggling writer's entire life from youth (Pather Panchali (The Song of the Road, 1955), Aparajito (The Unvanquished, 1956), and Apur Sansar (The World of Apu, 1959). Besides Satyajit Ray, Semih Kaplanolu also admits to being strongly influenced by the "metaphysical cinema" of Ozu, Bresson, and Tarkovsky.

The runner-up Special Jury Prize in the international competition at Istanbul was awarded to Dennis Gansel's Die Welle (The Wave) (Germany), a film dossier on how brainwashing works and destroys. A remake of Alexander Grasshoff's tele-feature The Wave (USA, 1981) - based in turn on a 1967 incident at an American high school that had inspired Morton Rhue's popular novella (1981) with the same title - Gansel's remake leans on the German translation (1984) of Rhue's story to effectively review how a school experiment on brain-washing and Nazi dictatorship led by a charismatic leftist teacher (Jürgen Vogel) could run amok during the learning process. Die Welle benefits from its fast narrative pace and natural performances by young actors - particularly Frederick Lau in the role of an impressionable student who runs the full gamut of the brain-washing experiment to an unforeseen tragic end. (A few weeks after the close of the Istanbul festival, The Wave received two German Lola Awards: Bronze Lola for Production and Best Supporting Actor to Frederick Lau.) 
In the Turkish Competition the Main Prize went to Seyfi Teoman's Tatil kitabi (Summer Book), previously screened at the Berlinale in the International Forum of New Cinema. Set in a provincial seacoast town, Summer Book chronicles the languid summer days of a boy whose father has suffered a crippling brain haemorrhage while on a business trip and now burdens the family with unknown facts about his hidden life. The Best Actress Award was deservedly won by Ayça Damgac for her tragicomic performance in the surreal docu-drama Gitmek (My Marlon and Brando), co-directed by herself and Hoseyin Karabey. Part fairy tale, part road movie, with several scenes enhanced by real-life documentary moments, My Marlon and Brando is the weird yet believable story of a Turkish girl in an independent theatre troupe who falls in love with a Kurdish actor while a film is being shot just over the border in Iraq. Later, when the pair are separated by the American occupation of Iraq, they can only communicate by phone calls and an apparent exchange of videos. Frustrated by the increasing breakdowns in communication, Anca makes the decision to travel to Iraq from Turkey by way of Iran - while her beloved "Marlon and Brando" is trying to cross illegally from Iraq to Turkey. What happens along the way is funny, farcical, absurd - a homemade video enlivened by the stubborn temperament of a woman who won't take no for an answer.

Last, but not least, was the launch of a new Human Rights Award as an integral part of the IIFF festival portfolio. The first FACE (Film Award of Council of Europe) Award was given to Li Yang's Mang shan (Blind Mountain, China). This FACE Award did not go unnoticed among press and public. Blind Mountain, the biting sociocritical story of a young woman kidnapped and "sold for marriage" to mountain villagers, can be viewed as a universal plea to recognize the rights of women in countries where archaic customs still prevail.

\section{References}

\section{AWARDS}

\section{International Jury}

Golden Tulip

Yumurta (Egg) (Turkey/Greece), dir Semih Kaplanolu

Special Jury Prize

Die Welle (The Wave) (Germany), dir Dennis Gansel

National Competition

Best Turkish Film

Tatil kitabi (Summer Book), dir Seyfi Teoman

Best Director

Dervi Zaim, Notka (Dot)

Best Actress

Ayça Damgac, Gitmek (My Marlon and Brando), dir Hoseyin Karabey, Ayça Damgac

Best Actor

Serhat Tutumluer, Ara, dir Ümit Ünal

Special Jury Prize

Ara, dir Ümit Ünal

Human Rights FACE Award (Film Award of Council of Europe)

Mang shan (Blind Mountain) (China), dir Li Yang

FIPRESCI Awards

International Competition

Ben X (Belgium), dir Nic Balthazar 
National Competition,

Tatil kitabi (Summer Book), dir Seyfi Teoman

People's Choice Awards

International Competition

Yumurta (Egg) (Turkey/Greece), dir Semih Kaplanolu

National Competition

Ulak (The Messenger), dir Çaan Irmak

\section{Author Information}

Ron HOLLOWAY (1933-2009) was an American critic, film historian, filmmaker and correspondent who adopted Europe as his home in the early fifties and spent much of his life in Berlin. He was an expert on the study of German cinema and against all odds produced, with his wife Dorothea, the journal German Film, keeping us up-to-date with the work of directors, producers and writers and the showing of German films around the world.

In 2007, Ron Holloway and his wife were awarded the Berlinale Camera Award. Ron also received the Bundesverdienstkreuz (German Cross of Merit), Polish Rings, Cannes Gold Medaille, the American Cinema Foundation Award, the Diploma for Support of Russian Cinema and an honorary award from the German Film Critics' Association.

Ron was also a valued contributor to Kinema for the past fifteen years. 